\title{
Mediating Effects of HRM Practices in Organizational Justice on Innovative Work Behavior among the Hotel Industry of Pakistan
}

\section{Uzma Ismail}

Faculty of Business Administration, Hajvery University, Lahore, Pakistan, E-mail: uzmaismail57@yahoo.com

\begin{abstract}
Justice is an important element in any organization. Innovative work behavior and Human Resource Management practices (HRMPs) are affected by organizational justice (Distributive, Procedural, Interpersonal \& informational). For this paper distributive justice is selected as an independent variable. The purpose of this paper is to explore the mediating effect of HRM practices in organizational justice on innovative work behavior among the hotel industry of Pakistan. In total, 151 personnel were selected from 21 hotels from different cities of Pakistan. The survey instrument was adapted for collecting data. Top/middle management is selected for this study, therefore, convenience and purposive sampling technique is adopted Findings were drawn using descriptive analysis, bivariate correlation, linear regression; and mediation was tested by using Prof.Hayes model 4 by using SPSS version 25. Results revealed that organizational justice is significantly related to the innovative work behavior of employees \& HRMPs significantly mediated. Findings of this study suggested that distributive justice is an important factor for creating innovative work behavior of employees. Further the top/middle management with higher organizational justice is taken to create new ideas with innovation which can be beneficial for the hotels and employees. The study provides essential information about the impact of distributive justice on innovative work behavior of employees of the hotel industry. The outcomes of this research are expected to improve further research and literature on organizational justice, HRM practices and innovative work behavior.
\end{abstract}

Key words

Organizational Justice, Innovative Work Behavior, HRM Practices, Hotel, Mediation

Received: 29 Feb $2020 \quad$ (c) The Authors 2020

Revised: 08 Mar 2020 Published by Human Resource Management Academic Research Society (www.hrmars.com)

Accepted: 12 Mar 2020 This article is published under the Creative Commons Attribution (CC BY 4.0) license. Anyone may Published Online: 17 Mar 2020 reproduce, distribute, translate and create derivative works of this article (for both commercial and non-commercial purposes), subject to full attribution to the original publication and authors. The full terms of this license may be seen at: http://creativecommons.org/licences/by/4.0/legalcode

\section{Introduction}

The hospitality industry is among the fastest-growing and critically challenging industries in the world (Buyers, 2017). Rapid development is recently observed in the regions of USA, Europe, the Middle East, East and Southeast Asia (Timetric, 2013). This industry emerged through the advancement of private enterprise, flexibility and conditional relations to geographic regions, which expanded the requirement for travel accommodations (G. Langford, 2016). Despite the growth and healthy prospect, it is facing immense human resource challenges in the form of Organizational Justice (OJ) due to increased competition in the market (Laforet, 2013).Organization justice is the most important component associated with any organization (Greenberg \& Colquitt, 2006). Employees of the organization will treat customers the same as they are being treated by their organization because it has a direct impact (Oren et al., 2013). That's why organizations should react or treat their employees in a positive manner so they would be able to treat customers in a polite manner. As organization justice plays a key role in all organizations (Al-Abrrow et al., 2013). From an organizational behavior and HRM field, organizational justice gained the highest importance 
in the past two decades (Jackson et al., 2014). It is essential for organizations to hire competent employees to achieve a competitive advantage in the market (Jackson et al., 2014.

In innovative work behavior, the fairness of perception is the most important factor that's why positive behavior depends on the fairness of perception in an organization (Mirkamali et al., 2010). Employees with a high perception of justice will act positively because healthy social interaction depends upon a fair perception of justice. In another case, failing to instill trustworthiness and justice, the management will be facing so many problems with respect to employee's behavior and their performance (Awang \& Ahmad, 2015). In fact, the fundamental purpose of applying innovated behaviors in human resource management practices is to provide competitive advantages (Jackson et al., 2014). In the wake of global competition, rapid technical changes, and changing customer demands are calling upon more efficient and effective operations in the hospitality industry in order to meet these challenges (Korczynski, 2002). In this scenario, the profitability of organizations depends upon meeting customer demands efficiently (Kaul \& Luo, 2016).

The fundamental values of organizational justice have important consequences for working organizations. This is basically related to HRM practices and practitioners because awareness of equality is important for every individual in an organization (Hazzi, 2012). As organizational justice reflects the fairness and consistency of actions (Jones \& Skarlicki, 2013) so, it will enhance the understanding of efficient human resource practices with innovative work behavior. Researches in Organizational context extend their emphasis that injustice in the workplace leads to negative and unfortunate responses (Krischer et al., 2010; Devonish \& Greenidge, 2010). Encountering injustice may result in decreased power for decision making (Sulu et al., 2010). Along that injustice in the workplace will result in a negative outcome and negative behavior (Krischer et al., 2010) increase job burnouts and decrease employee performance. Organizational injustice has received so much attention in recent research as its effect on the mental and physical health of employees, specifically, researchers demonstrated that absence of organizational justice is linked to pressure and negative behavior of employees at work and negative work alienation (Ceylan \& Sulu, 2011; Sookoo, 2014). Injustice provokes intense emotion in most people, and the more pertinent that injustice is to our own particular lives and experience, the more we faced difficulties and negativities, we start reacting and thinking in the same manners and perceive that every single thing is going in the wrong way (Silva et al., 2012).

This study utilizes the organizational justice models of Colquitt's (2001) and Niehoff and Moorman (1993) along this innovative work behavior model developed by (Janssen 2000). The primary purpose of this study was investigating the impact of organizational justice on innovative work behavior of employees and how Human Resource Management Practices impact this relationship as mediator in hotel industry of Pakistan.

\subsection{Background of the study}

A brief literature review that depicts the key concepts of organizational justice, innovative work and HRM practices. Some of the important empirical studies, that emphasis on the relation between these variables from literature is listed. Finally, based on the literature reviews hypotheses are developed for this study. Concept of organizational justice is based on Adam Equity theory. It was developed by the American psychologist John Stacey Adams in 1963. As Adams (1965) mentioned people look at their input and their resulted outputs with others input and output in a similar working environment. This is significant for the organizational justice perception of an individual. Concept of Innovative work behavior and HRM practices are based on social cognitive theory. This theory came from Edwin B. Holt and Harold Chapman Brown's 1931 book conceptualized that all human activities depend on satisfying the mental needs of feeling, feeling, and want.

\subsection{Research objectives}

1. To explore the impact of organizational justice (distributive, procedural, informational, interactional) on innovative work behavior of employees in the hotel industry.

2. To identify the mediating effect of HRM practices between the relationship of organizational justice and innovative work behavior of employees working in hotels. 


\section{Literature review}

\subsection{Organizational Justice}

The concept of Organizational justice (OJ) flourished substantially when distributive justice was introduced by Homans. After that, social scientists started to view the fundamental aspects of human behavior with respect to OJ. Research Scholar like Blau \& Adam started to pay attention to OJ in organizational behavior studies. The concept of OJ was derived from equity theory given by (Adams, 19631965). Greenberg (1987) stated that Organizational justice is the employee's perception of fairness within an organization. Pekurinen et al. (2017) defined Justice is perceived as an activity or choice that is known to be ethically right keeping in mind of moral, religious, equality and equity. Greenberg (2006) categorized organizational justice in three forms which are distributive justice (DJ), procedural justice (PJ), and interactional justice (IJ) which is further divided into two forms which are informational justice (INFJ) and interpersonal justice (IPJ). A range of researches conducted on organizational justice (OJ) in a different perspective with all its four sub-variables, i.e. Distributive Justice (DJ), Procedural Justice (PJ), Interpersonal Justice (IJ), and Informational Justice (INFJ) are Pan et al., 2018; Lambert, 2018; Erdoğdu, 2018; Saad, 2017.

Consequences of organizational justice in the hotel industry;

- The strong positive effect of organizational justice on employees' support (Pablo \& Jyh-Ming, 2017).

- Highest level of association between organizational justice and customer satisfaction (Umar et al., 2016)

- A significant positive relationship between procedural justice and organizational commitment (Gamage, 2014).

\subsection{Innovative Work Behavior}

Innovation is a fundamental factor for associations to adjust to quick monetary changes for maintaining competitive advantage (Hitt et al., 1998). That's why innovation and people gained more attention in every field. Almost three decades ago Van de Ven (1986) figured out that people are the individuals who create, encourage, react, and revise thoughts, which are essential necessities and most important factors for development. Janssen conceptualized that innovative work behavior (IWB) is a purposeful creation, presentation, and use of new thoughts within work, gathering or association, to benefit work performance, the gathering or the association. De Jong and Hartog (2010) figured out four interrelated arrangements of behavioral aspects idea recognition, idea generation, idea promotion, idea realization; these could improve the creativity and performance of employees.

Consequences of innovative work behavior in the hotel industry;

- There is a strong relationship between psychological safety and innovative work behavior of employees (Alzyoud et al., 2017)

- Behavior regarding team culture and knowledge sharing has the highest impact on service innovation performance (Hussaina et al., 2015).

- The study signified that procedural justice has a positive impact on knowledge sharing and knowledge sharing has on innovative work behavior (Noerchoidah \& Harjanti, 2019).

\subsection{Organizational Justice and Innovative Work Behavior}

Organizational justice is the most important factor nowadays because employee's behaviors are based on justice in organizations (Heidari \& Saeedi, 2012). The paradigm of behavior is shifting towards innovative behavior; generally, innovation and specifically innovative work behavior are the core aspect in the hospitality industry (de Spiegelaere et al., 2014). Researchers investigated the impact of Organizational justice on different variables related to behavior i.e. Pan et al. (2018) positive organizational behavior; (Lambert et al., 2018; DeConinck, 2010) work attitudes; Sulaiman (2018) counterproductive behavior (Gan \& Yusuf 2018, Leelamanothum \& Ngudgratoke, 2018; Yuen et al., 2018) organizational citizenship behavior.

As Innovative work behavior was examined with organizational justice collectively, therefore, no study from literature was found in which all three elements of innovative work behavior (idea generation, idea promotion, and idea realization) were tested with all elements of organizational justice. Hence, numerous researchers tested this element with others variables i.e. Niesen et al. (2018) conducted the 
study to explore the relationship between job insecurity and IWB (Idea generation, Idea Promotion, idea implementation) and concluded negative relation between idea generation and idea implementation. Based on this hypothesis is formulated to test the impact of organizational justice and its elements (distributive, procedural, interpersonal, and informational) on innovative work behavior and its elements (idea generation, idea promotion, and idea realization).

Hypothesis: Organizational justice (distributive, procedural, interpersonal, information) has a positive impact on innovative work behavior (idea generation, idea promotion, idea realization).

\subsection{Human Resource Management Practices}

Human Resource is the most vital resource for any organization plus it is the best source for achieving competitive advantage for any organization. This is the era of technology and innovation, so day by day; it's becoming so challenging for HR managers to manage effectively. Organizations need an effective HRM system to compete and sustain competitive advantage. As Khatri (1999) argued, for any organization people are the most important asset who adopts change for the betterment of the organization. The effective HRM structure helps organizations to improve the attitudes and behavior that will ultimately lead to improving the performance of employees (Koch \& McGrath, 1996). Human Resource Management (HRM) rose in the mid-1980s and keeps on advancing as a different field of study (Hendry \& Pettigrew, 1990). As Schuler and Jackson (2014) conceptualized HRM practices as a framework that appeals, progresses, encourage, and retains employees to guarantee the effective implementation and the survival of the organization and its individuals.

Different researchers defined the concept of HRM in different ways i.e. (Harter et al., 2002) increased knowledge and motivate employees, (Delery \& Doty, 1996) policies for implementing business objectives, (Minbaeva, 2005) help to manage human resources (Damampour \& Gopalakrishnan, 1998; Tan \& Nasurdin, 2010) positive work behaviors among employees (Hilsop, 2003; Morrow \& McElroy, 2001; Moynihan et al., 2001; Rousseau \& Greller, 1994) HRM practices and organizational innovation (Joseph \& Dai, 2009) HRM practices and performance (Hornsby \& Kuratko, 1990) HRM practices and SMEs (Huselid, 1995) HRM practices and turnover productivity (Schuler, 1992) strategic human resource management. HRM practices help to improve the performance and behavior of the employees. Positive behavior is necessary for the implementation of HRMPs. More crucial aspects of consideration the in recent years in the hotel industry:

- Human capital significantly mediated the relationship between human resource management practices and innovation performance (Nieves \& Quintana, 2016);

- A significant gap was identified between the new employee and the existing pool. Only compensation practices showed a significant relation (Bagri et al., 2010);

- Selection and assessment methods in hotels are resume and recruitment interview rather than interest, attitude, and preference (Chan \& Kuok, 2011).

\subsection{Organizational Justice, Innovative Work Behavior and Human Resource Management Practices}

In the working atmosphere, human resource management practices and organizational justice are the key components. Numerous studies are conducted to highlight the importance of HRM practices with different outcomes (performance, satisfaction, productivity) most prominent is organizational performance i.e. Hee \& Jing, (2018), Ahmed et al., (2018), Hoque et al,. (2018), Mbiu \& Nzulwa, (2018),_Okechukwu (2017), Amyan (2016) employees performance. Results of these studies showed a positive impact of HRM practices on performance. Perception of fairness in the working atmosphere has become the dominant figure in the last decade. Employees can perform well if they are treated well in the organization (Colquitt et al., 2005). So, different researcher highlighted the role of organizational justice with HRM practices:

- Distributive justice had a positive impact on both types of engagement but procedural justice had not and interactional justice had a partial impact on organizational engagement (Lamprakis et al., 2018).

- Organizational justice has a positive correlation on HRM practices (promotion, performance appraisal remuneration practices) (Yiğitol \& Balaban, 2018).

Various researchers investigated HRM practices with different behaviors like organizational citizenship behavior, innovative work behavior.

- HRM is important for improving behavior and performance (Zhang, 2016). 
- Human resource management practices improve the innovative work behavior of employees. (Bücker \& Horst, 2017).

HRM practices as a framework that appeals to progress, encourage and retains employees to guarantee effective implementation and the survival of the organization and its individuals. Based on the literature following hypothesis are formulated to check the moderating and mediating impact of HRM practices between the relationship of organizational justice and innovative work behaviors.

Hypothesis: HRM Practices mediate the relationship between organizational justice and innovative work behavior.

\subsection{Conceptual Framework}

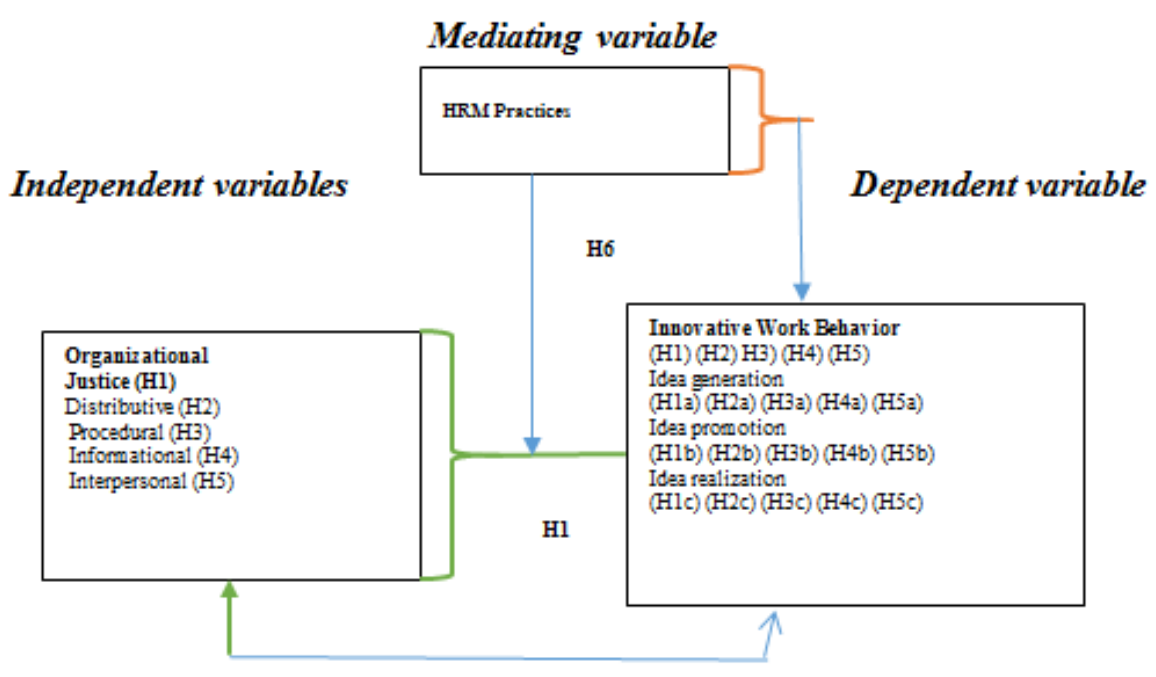

Figure 1. Conceptual Framework

Source: Created by the author based on literature

\section{Methodology of research}

\subsection{Overview of Research Methodology Elements}

The quantitative design has been selected for this particular reason study, along with the primary quantitative nature of data. The rationale behind the selection of a quantitative design is that it best fits the subject matter in the discussion and the objectives of the study as they have phrased. The next component of research methodology is research philosophy; contemporary research has described two distinct philosophies of research which are fundamental in nature: positivism and interpretivism. The philosophy of interpretivism goes along the lines of a qualitative research design in which qualitative data analysis and data collection techniques are used. As per this particular research philosophy, the research philosophy aims to interview preferably human research participants in order to gain an in-depth insight into the observed phenomenon. On the other hand, research philosophy of positivism aims to collect and analyze quantitative data so as to statistically validate the theoretical underpinnings of an observed phenomenon. This research is characterized by a quantitative research design and hence the research philosophy of positivism underpins the study. A third research philosophy is the philosophy of pragmatism, which is characterized by a mixed methods design of the study. However, this has been regarded as a hybrid form of research philosophies derived from the two fundamental philosophies. Another important research methodology component is that of the research approach; two distinct approaches to research have been described in contemporary literature. These are the inductive and the deductive approaches. The inductive approach commences the research activity from observation to a deduction of an outcome as to how a particular phenomenon occurs in the realm of reality. On the contrary, deductive approach commences research activity from the formulation of hypothesis pertaining to an observed phenomenon and ends the activity after conducting a statistical validation of those hypotheses. In this particular context, no new theory is created. This particular research study adopts a deductive approach towards research. 


\subsection{Sample Size and Sampling Strategy}

This research was conducted on different hotels located in different cities of Pakistan i.e. Islamabad, Rawalpindi, Karachi, and Multan with the aim to investigate the mediating effects of HRMPs in organizational justice on innovative work behavior. A quantitative approach is adopted for conducting this survey. This study adopted a multi-stage sampling approach consisting of Convenience and Purposive sampling. Top and Middle management were targeted as they have knowledge, experience and a better understanding regarding various aspects of Organizational justice, HRMPs and innovative work behavior. For data collection 21 hotels were selected. Data was collected by distributing questionnaires, personally visiting all hotels one by one and collected by hand. A total of 154 questionnaires were designed for data collection and 151 filled questionnaires were received. The response rate is given in (Table 1) Data was compiled through ethical code standard and, Statistical Package for Social Sciences (SPSS) version 25 was used for data analysis. All participants were well informed about this study. Further, it was cleared in the questionnaire that their data would be used confidentially and only for the research purpose.

Table 1. Response rate

\begin{tabular}{cccccc}
\hline Selected Industry & Distributed & Received & Not received & Rejected & Response rate \\
\hline Hotels & 154 & 151 & 3 & 0 & $98 \%$ \\
\hline
\end{tabular}

\section{Source:Created by author}

\subsection{Data Collection}

A structured questionnaire was utilized to make sure that there was standardization in the response given and in the gathering of data. So, data was collected from respondents through the questionnaire. Questionnaires against all variables are adopted and measured using five-point Likert's scale starting from strongly disagrees to strongly agree/very little extent to a very great extent. For measuring organizational justice scale of (Colquitt's, 2001) and (Niehoff and Moorman, 1993) is adopted. The items for Distributive justice (DJ) and Procedural justice (PJ) are adapted from (Niehoff and Moorman, 1993). The questionnaire to measure Distributive justice and Procedural justice included items such as "My work schedule is fair." and "My hotel has procedures to collect information for making decisions accurately and thoroughly". The items for Interpersonal justice and Informational justice are adapted from (Colquitts, 2001). The questionnaire to measure Interpersonal Justice (IJ) and Informational justice (INFJ) included items such as "I am being treated in a polite manner in my hotel." and "Details are communicated in a timely manner". For Innovative work behavior scale of (Jansen, 2000) is adopted that represented nine items and measured the extent of individual idea generation, promotion, and implementation. The questionnaire to measure Idea Generation (IG), Idea Promotion (IP), and Idea Realization (IR) included items such as "I am creating new ideas for difficult issues", "I am mobilizing support for innovative ideas "and "I am transforming innovative ideas into useful applications". For HRMPs scale of (Chen and Huang (2009) and Masood (2010) is adopted. The questionnaire to measure HRMPs included items such as "Valid and standardized tests are used in the selection process of employees" and "Formal training activities are available in my hotel".

\subsection{Ethical Considerations}

Two ethical considerations are an important part of the discussion. The first ethical consideration in the context of this study is that of maintaining the anonymity of the research respondents; even before inviting the survey respondents to participate in the research study, they were assured complete masking of their identity. The second important ethical consideration was that of maintaining the confidentiality of the survey respondents. The respondents were completely ensured that all of their responses to the survey questionnaire will be absolutely confidential and no compromise on the confidentiality of responses will be made.

\section{Results}

\subsection{Reliability Testing}

The reliability of the survey questionnaire was the first factor to be assessed quantitatively. For this, Cronbach Alpha value was used. According to Osburn (2000), the value of Cronbach Alpha is used so as to 
test statistically the reliability of the constructs involved in the research study under consideration. The magnitude of reliability for this study is 0.761 , which is suggestive of the fact that the survey designed for the purpose of data collection is reliable.

Table 2. Reliability Statistics

Source: SPSS findings

\begin{tabular}{cc}
\hline Cronbach' alpha & N of Items \\
0.761 & 50 \\
\hline
\end{tabular}

\subsection{Demographic Profile}

As many as eight different variables were used to gauge the demographic positioning of the respondents. These variables included gender, education, current position, household income, current status, tenure and supervision of staff. It was determined that around $81.45 \%$ of the respondents were males. The age of most of the respondents ranged from 20 years to 45 years, whereas the education level of most of the candidates was bachelors and masters. This indicates that the employees are capable to compete with their competitors and also have the flexibility to act according to the dynamics of the market. Table 3 summarizes the demographic analysis.

Table 3. Demographic Analysis

\begin{tabular}{|c|c|c|c|}
\hline Characteristics & Male $n=123$ & Female $n=28$ & Total $n=151$ \\
\hline \multicolumn{4}{|l|}{ Age } \\
\hline$<25$ & $19(12.6 \%)$ & $7(4.6 \%)$ & $26(17.2 \%)$ \\
\hline $25-30$ & $4(2.6 \%)$ & 0 & $4(2.6 \%)$ \\
\hline $30-35$ & $38(25.2 \%)$ & $11(7.3 \%)$ & $49(32.5 \%)$ \\
\hline $35-40$ & $38(25.2 \%)$ & $9(6 \%)$ & $47(31.5 \%)$ \\
\hline $40-45$ & $19(12.6 \%)$ & $1(0.7 \%)$ & $20(13.21 \%)$ \\
\hline$>45$ & $5(3.3 \%)$ & 0 & $5(3.3 \%)$ \\
\hline \multicolumn{4}{|l|}{ Education } \\
\hline Inter & $1(0.7 \%)$ & 0 & $1(0.7 \%)$ \\
\hline Bachelor & $31(20.5 \%)$ & $4(2.6 \%)$ & $35(23.2 \%)$ \\
\hline Master & $85(56.3 \%)$ & $24(15.9 \%)$ & $109(72.2 \%)$ \\
\hline MPhil & $4(2.6 \%)$ & 0 & $4(2.6 \%)$ \\
\hline Other & $2(1.3 \%)$ & 0 & $2(1.3 \%)$ \\
\hline \multicolumn{4}{|l|}{ Current Profession } \\
\hline CEO & $2(1.3 \%)$ & 0 & $2(1.3 \%)$ \\
\hline Director & $25(16.6 \%)$ & $1(0.7 \%)$ & $26(17.2 \%)$ \\
\hline Manager & $54(35.8 \%)$ & $16(10.6 \%)$ & $70(46.4 \%)$ \\
\hline Administrative Assistant & $18(11.9 \%)$ & $4(2.6 \%)$ & $22(14.6 \%)$ \\
\hline Advisor & $5(3.3 \%)$ & $1(0.7 \%)$ & $6(4 \%)$ \\
\hline Middle Management & $19(12.6 \%)$ & $6(4 \%)$ & $25(16.6 \%)$ \\
\hline \multicolumn{4}{|l|}{ Income } \\
\hline$<20000$ & $13(8.6 \%)$ & $2(1.3 \%)$ & $15(9.9 \%)$ \\
\hline $20000-300000$ & $7(4.6 \%)$ & $2(1.3 \%)$ & $9(6 \%)$ \\
\hline $30000-40000$ & $8(5.3 \%)$ & $1(0.7 \%)$ & $9(6 \%)$ \\
\hline $40000-50000$ & $24(15.9 \%)$ & $7(4.6 \%)$ & $31(20.5 \%)$ \\
\hline$>50000$ & $71(47 \%)$ & $16(10.6 \%)$ & $87(57.6 \%)$ \\
\hline \multicolumn{4}{|l|}{ Working Year(s) } \\
\hline $0-2 y r s$ & $41(27.2 \%)$ & $11(7.3 \%)$ & $52(34.4 \%)$ \\
\hline 3-5 yrs. & $34(22.5 \%)$ & $8(5.3 \%)$ & $42(27.8 \%)$ \\
\hline 6-8yrs & $25(16.6 \%)$ & $8(5.3 \%)$ & $33(21.9 \%)$ \\
\hline $9-10 y r s$ & $14(9.3 \%)$ & 0 & $14(9.3 \%)$ \\
\hline$>10$ yrs. & $9(6 \%)$ & $1(0.7 \%)$ & $10(6.6 \%)$ \\
\hline \multicolumn{4}{|l|}{ Staff Supervision } \\
\hline 1-3employees & $30(19.9 \%)$ & $7(4.6 \%)$ & $37(24.5 \%)$ \\
\hline 4-7 employees & $24(15.9 \%)$ & $5(3.3 \%)$ & $29(19.2 \%)$ \\
\hline 8-10 employees & $22(14.6 \%)$ & $5(3.3 \%)$ & $27(17.9 \%)$ \\
\hline$>10$ employees & $36(23.8 \%)$ & $6(4 \%)$ & $42(27.8 \%)$ \\
\hline None & $11(7.3 \%)$ & $5(3.3 \%)$ & $16(10.6 \%)$ \\
\hline
\end{tabular}

Source: Created by the author based on findings 


\subsection{Correlation Analysis}

According to statistical results, the value of Pearson correlation (Table 4), between organization justice (M_ORG) and innovative work behavior (M_IWB) is 0.377 . This shows a positive and a direct association between organizational justice and innovative work behavior. The association between organizational justice (M_ORG) and human resource management (M_HRMPs) is 0.732 , which also shows a strong relationship. Similarly, the magnitude of correlation between the variables M_HRMPs and M_IWB is 0.401 , which shows that there is a positive relationship between human resource management practices and innovative work behavior. Further, the magnitude of correlation between the variables M_ORG and M_IWB is 0.314 . This is suggestive of the fact that there is a positive/direct but weak relationship between organizational justice and human resource management practices. Overall and holistically, the outcomes that have been obtained reflect an overall positive association between the dependent and independent variables.

Table 4. Pearson Correlation

\begin{tabular}{|c|c|c|c|c|c|c|c|c|c|c|c|c|c|c|}
\hline & Mean & SD & 1 & 2 & 3 & 4 & 5 & 6 & 7 & 8 & 9 & 10 & 11 & 12 \\
\hline \multicolumn{3}{|c|}{ Organizational justice } & & & & & & & & & & & & \\
\hline $\begin{array}{l}\text { 1. Distributive } \\
\text { justice }\end{array}$ & 3.9179 & 0.40482 & $(0.75)$ & & & & & & & & & & & \\
\hline $\begin{array}{l}\text { 3.Interpersonal } \\
\text { justice }\end{array}$ & 3.8543 & 0.57905 & 0.067 & $.247^{* *}$ & $(0.77)$ & & & & & & & & & \\
\hline $\begin{array}{l}\text { 4.Informational } \\
\text { justice }\end{array}$ & 3.9457 & 0.49956 & 0.118 & $.355^{* *}$ & -0.038 & $(0.76)$ & & & & & & & & \\
\hline \multicolumn{3}{|c|}{ Innovative work behavior $\quad(\mathbf{0 . 7 3 )}$} & & & & & & & & & & & & \\
\hline $\begin{array}{l}\text { 5.Idea } \\
\text { generation }\end{array}$ & 4.2759 & 0.43676 & 0.091 & $.252^{* *}$ & $.215^{* *}$ & 0.063 & $(0.75)$ & & & & & & & \\
\hline 6.Idea promotion & 4.2671 & 0.41100 & 0.143 & $.165^{*}$ & 0.116 & $.220^{* *}$ & 0.003 & $(0.75)$ & & & & & & \\
\hline 7.Idea realization & 4.2208 & 0.43014 & -0.048 & $.227^{* *}$ & 0.034 & $.209^{* *}$ & $.222^{* *}$ & -0.001 & $(0.75)$ & & & & & \\
\hline \multicolumn{3}{|c|}{ Human resource management practices } & \multicolumn{2}{|c|}{$(0.73)$} & & & & & & & & & & \\
\hline 8.Staffing & 4.2252 & 0.47413 & 0.043 & 0.152 & 0.079 & 0.094 & 0.103 & 0.143 & $.332^{* *}$ & $(0.75)$ & & & & \\
\hline 10.Compensation & 4.2274 & 0.42925 & 0.103 & $.378^{* *}$ & $.208^{*}$ & 0.135 & 0.038 & 0.103 & 0.083 & 0.153 & 0.032 & $(0.75)$ & & \\
\hline $\begin{array}{l}\text { 11.Performance } \\
\text { Appraisal }\end{array}$ & 3.9702 & 0.52593 & 0.145 & $.201^{*}$ & 0.029 & -0.148 & 0.133 & $.227^{* *}$ & 0.103 & 0.126 & $.237^{* *}$ & -0.122 & $(0.76)$ & \\
\hline 12.Participation & 4.1113 & 0.44039 & $.200^{*}$ & $.247^{* *}$ & 0.008 & 0.037 & 0.156 & 0.105 & 0.083 & 0.135 & $.270^{* *}$ & $.211^{* *}$ & 0.124 & $(0.75)$ \\
\hline
\end{tabular}

Notes: $\mathrm{n}=151$. Reliabilities in parentheses. Scale anchors: 1 (strongly disagree) to 5 (strongly agree). ${ }^{*} \mathrm{p} \leqslant 0.05 ;{ }^{* *} \mathrm{p} \leqslant 0.01 ;{ }^{* * *} \mathrm{p} \leqslant 0.001$

\section{Source: Created by the author based on SPSS result}

\subsection{Regression analysis and Hypothesis Testing}

Regression analysis outlines to what extent any change in the independent variable triggers a change in the dependent variable (Aiken \& West, 1991). In this study, organizational justice with its four constructs had been selected as the independent variable, whereas innovative work behavior had been considered as the dependent variable.

Firstly, the effect of organizational justice on innovative work behavior was estimated (H1). Empirical evidence suggests that there is a positive/significant relationship of organizational justice with innovative work behavior. The estimation of R2 0.142 demonstrates that this model explains $14.2 \%$ of the effect of organizational justice on innovative work behavior while the remaining is explained by other different variables. F-Value (24.673) demonstrates that the model is significant. The beta coefficient value of organizational justice is 0.327 , which means that every unit increase in organizational justice will result in 0.327 units increase or appreciation in the variable of innovative work behavior at a significant level of $\mathrm{P}<0.05=>0.000<0.05$. Consequently, the researcher concluded that at $95 \%$ confidence interval, there is a failure to reject the null hypothesis on the basis of findings. The effect of organizational justice was estimated on sub-variables of innovative work behavior which are idea generation, idea promotion, and idea realization, at a significant level of $\mathrm{P}<0.05=>0.002>0.05$ for $(\mathrm{H} 1 \mathrm{a}) ; \mathrm{P}<0.05=>0.001>0.05$ for $\mathrm{H} 1 \mathrm{~b}$ and $\mathrm{P}<$ $0.05=>0.021>0.05$ for $\mathrm{H} 1 \mathrm{c}$. So, the researcher concluded that at $95 \%$ confidence interval, there is a failure to reject the null hypotheses $\mathrm{H} 1 \mathrm{a}, \mathrm{b}$, and $\mathrm{c}$. 
Secondly, the effect of distributive justice on innovative work behavior was estimated (H2). Empirical evidence proves that there is an insignificant relationship. The estimation of R2 0.010 demonstrates that this model explains only $0.1 \%$ effect of distributive justice on innovative work behavior and remaining is explained by another different variable. F-Value (1.456) demonstrates that the model is insignificant. The beta coefficient of distributive justice is 0.064 . That means that every unit increase in distributive justice will result in 0.064 unit increase in innovative work behavior. The significance level of $P>0.05$ that is $0.229>0.05$. The researcher therefore fails to accept the null at a $95 \%$ confidence interval on the basis of findings. The significance level of $\mathrm{P}<0.05$ that is $0.265>0.05$ for $\mathrm{H} 2 \mathrm{a}, \mathrm{P}<0.05$ that $0.079>0.05$ for $\mathrm{H} 2 \mathrm{~b}$, and $\mathrm{P}<0.05$ that is $0.556>0.05$ for $\mathrm{H} 2 \mathrm{c}$. The researcher therefore fails to accept the null for $\mathrm{H} 2 \mathrm{a}, \mathrm{H} 2 \mathrm{~b} \mathrm{H} 2 \mathrm{c}$ on the basis of findings.

Thirdly, the effect of procedural justice on innovative work behavior was estimated (H3). Empirical evidence proves that there is a positive/significant relationship of organizational justice towards innovative work behavior. The estimation of R2 0.120 demonstrates that this model explains $12.0 \%$ effect of organizational justice on innovative work behavior and remaining is explained by another different variable. F-Value (20.406) demonstrates that the model is significant. The beta coefficient of procedural justice is 0.194 , which means that every unit increase in organizational justice will result in 0.194 unit increase in innovative work behavior. As a significant level of $\mathrm{P}<0.05=>0.000<0.05$. So, the researcher concluded at $95 \%$ confidence interval is failed to reject the $\mathrm{H} 3$ (alternate) and failed to accept the null hypothesis on the basis of findings. As significant level of $\mathrm{P}<0.05=>0.002>0.05$ for H3a; $\mathrm{P}<0.05=>0.043<0.05$ for $\mathrm{H} 3 \mathrm{~b}$; $\mathrm{P}<0.05=>0.005<0.05$ for $\mathrm{H} 3 \mathrm{c}$. So, the researcher concluded at $95 \%$ confidence interval is failed to reject the $H 3 a, b, c$ (alternate) and failed to accept the null hypothesis on the basis of findings.

Fourthly, the effect of interpersonal justice on innovative work behavior was estimated (H4). Empirical evidence proves that there is a positive/significant relationship of organizational justice towards innovative work behavior. The estimation of R2 0.039 demonstrates that this model explains the $0.39 \%$ effect of organizational justice on innovative work behavior and remaining is explained by another different variable. F-Value (6.000) demonstrates that the model is significant. The beta coefficient of interpersonal justice is 0.090 , which means that every unit increase in organizational justice will result in 0.090 unit increase in innovative work behavior. As significant level of $\mathrm{P}<0.05=>0.015<0.05$. So, the researcher failed to reject the $\mathrm{H} 4$ (null) on the basis of findings. The significance level of $\mathrm{P}<0.05$ that is $0.008<0.05$ for $\mathrm{H} 4 \mathrm{a}$, $\mathrm{P}<0.05$ that is $0.158>0.05$ for $\mathrm{H} 4 \mathrm{~b}$ and $\mathrm{P}<0.05$ that is $0.678>0.05$ for $\mathrm{H} 4 \mathrm{c}$. Consequently, the researcher fails to reject the null for $\mathrm{H} 4 \mathrm{a}$, fails to accept the null for $\mathrm{H} 4 \mathrm{~b}$, and fails to accept the null for $\mathrm{H} 4 \mathrm{c}$.

Fifthly, the effect of informational justice on innovative work behavior was estimated (H5). Empirical evidence proves that there is a significant relationship of interpersonal justice towards innovative work behavior. The estimation of R2 0.069 demonstrates that this model explains a $0.69 \%$ effect of organizational justice on innovative work behavior and remaining is explained by another different variable. F-Value (11.020) demonstrates that the model is significant. The beta coefficient of informational justice is 0.139 , which means that every unit increase in organizational justice will result in 0.139 unit increase in innovative work behavior. As a significant level of $P<0.05=>0.001<0.05$. So, the researcher concluded at $95 \%$ confidence interval that there is a failure to reject the $\mathrm{H} 5$ (null) on the basis of findings. As significant level of $\mathrm{P}<0.05=>0.442>0.05$ for $\mathrm{H} 5 \mathrm{a} ; \mathrm{P}<0.05=>0.007<0.05$ for $\mathrm{H} 5 \mathrm{~b} ; \mathrm{P}<0.05=>0.010<0.05$. So, it is concluded at $95 \%$ confidence interval researcher is failed to accept the $\mathrm{H} 5 \mathrm{a}$ (alternate) and failed to reject the H5b, c (null) on the basis of findings. The results are depicted in Table-5.

Table 5. Hypothesis Testing- Regression Analysis

\begin{tabular}{cccccccc}
\hline Model & \multicolumn{2}{c}{ Variables } & R2 & F-Value & Beta-Value & Sig & Hypothesis \\
\hline & IV & DV & & & & & \\
H1 & Org_J & IWB & 0.142 & 24.673 & 0.327 & 0.000 & Accepted \\
H1a & Org_J & IG_IWB & 0.065 & 10.382 & 0.366 & 0.002 & Accepted \\
H1b & Org_J & IP_IWB & 0.067 & 10.717 & 0.350 & 0.001 & Accepted \\
H1c & Org_J & IR_IWB & 0.035 & 5.478 & 0.266 & 0.021 & Accepted \\
H2 & DIS_J & IWB & 0.010 & 1.456 & 0.064 & 0.229 & Rejected \\
H2a & DIS_J & IG_IWB & 0.008 & 1.253 & 0.099 & 0.265 & Rejected \\
H2b & DIS_J & IP_IWB & 0.021 & 3.128 & 0.146 & 0.079 & Rejected
\end{tabular}




\begin{tabular}{cccccccc}
\hline Model & \multicolumn{2}{c}{ Variables } & R2 & F-Value & Beta-Value & Sig & Hypothesis \\
\hline H2c & DIS_J & IR_IWB & 0.002 & 0.349 & -0.051 & 0.556 & Rejected \\
H3 & PRO_J & IWB & 0.120 & 20.406 & 0.194 & 0.000 & Accepted \\
H3a & PRO_J & IG_IWB & 0.063 & 10.074 & 0.233 & 0.002 & Accepted \\
H3b & PRO_J & IP_IWB & 0.027 & 4.176 & 0.144 & 0.043 & Accepted \\
H3c & PRO_J & IR_IWB & 0.051 & 8.069 & 0.206 & 0.005 & Accepted \\
H4 & I_J & IWB & 0.039 & 6.000 & 0.090 & 0.015 & Accepted \\
H4a & I_J & IG_IWB & 0.046 & 7.217 & 0.162 & 0.008 & Accepted \\
H4b & I_J & IP_IWB & 0.013 & 2.018 & 0.082 & 0.158 & Rejected \\
H4c & I_J & IR_IWB & 0.001 & 0.173 & 0.025 & 0.078 & Rejected \\
H5 & INF_J & IWB & 0.069 & 11.020 & 0.139 & 0.001 & Accepted \\
H5a & INF_J & IG_IWB & 0.004 & 0.594 & 0.055 & 0.442 & Rejected \\
H5b & INF_J & IP_IWB & 0.049 & 7.613 & 0.181 & 0.007 & Accepted \\
H5c & INF_J & IR_IWB & 0.044 & 6.820 & 0.180 & 0.010 & Accepted \\
\hline
\end{tabular}

Source: Created by the author based on SPSS results

\subsection{Mediation Analysis (Prof.Andrew Hayes Model 4)}

To test the mediation, Sobel test or Prof. Andrew Hayes Model (Model 4) was used. Empirical evidence proves that HRMPs significantly mediated the relationship between organizational justice and innovative work behavior. The direct effect of $x$ on $y$ is $p<0.0003$, and since " 0 " does not fall between the lower and upper limit values, there seems to be an indirect impact. R2 mediation effect magnitude is $\mathrm{P}<$ 0.0309 which is significant. Along with this, the $p$-value of normal theory checks for the indirect effect; this checking yields that the $\mathrm{p}$-value is $\mathrm{P}<0.0044$, which is significant. So, it is concluded at $95 \%$ confidence interval that there is a failure to reject the $H 6$ (null). Results are given in Table- 6 .

Table 6. Mediation Analysis

\begin{tabular}{|c|c|c|c|c|c|c|}
\hline \multicolumn{7}{|c|}{ Model Summary } \\
\hline $\mathbf{R}$ & $R-s q$ & MSE & $\mathbf{F}$ & df1 & df2 & $\mathbf{P}$ \\
\hline 0.4806 & 0.231 & 0.0454 & 22.2268 & 2.0000 & 148.000 & 0.0000 \\
\hline \multicolumn{7}{|l|}{ Model } \\
\hline & Coeff & Se & $\mathrm{t}$ & $P$ & LLCl & ULCI \\
\hline Constant & 1.986 & 0.3423 & 5.8018 & 0.0000 & 1.3096 & 2.6625 \\
\hline M_HRMPS & 0.3178 & 0.0768 & 4.1367 & 0.0001 & 0.166 & 0.4696 \\
\hline M_ORG & 0.2418 & 0.0659 & 3.6677 & 0.0003 & 0.1115 & 0.3721 \\
\hline \multicolumn{7}{|c|}{ The direct effect of $X$ on $Y$} \\
\hline & Effect & SE & $\mathrm{t}$ & $P$ & LLCl & ULCI \\
\hline & 0.2418 & 0.0659 & 3.6677 & 0.0003 & 0.1115 & 0.3721 \\
\hline \multicolumn{7}{|c|}{ The indirect effect of $X$ on $Y$} \\
\hline & Effect & BootSE & BootLLCI & BootULCI & & \\
\hline M_HRMPS & 0.0855 & 0.0318 & 0.0335 & 0.1593 & & \\
\hline \multicolumn{7}{|c|}{ R-squared mediation effectsize (R-sq_med) } \\
\hline & Effect & BootSE & BootLLCI & BootULCI & & \\
\hline M_HRMPS & 0.0722 & 0.0309 & 0.0245 & 0.1487 & & \\
\hline \multicolumn{7}{|c|}{ Normal theory tests for the indirect effect } \\
\hline & Effect & $\mathrm{Se}$ & $\mathrm{Z}$ & $P$ & & \\
\hline & 0.0855 & 0.0301 & 2.845 & 0.0044 & & \\
\hline
\end{tabular}

Source: SPSS results

\section{Discussion and implementation}

This study discusses the enhancement of knowledge in the hospitality sector specifically the hotel industry in terms of understanding the organizational justice and the behavior of employees working in the hotel industry. Initially, the concept of organizational justice was based on the promotion of justice and fairness among the employees working in the organization and this concept also determined the implementation of fairness in form of the distribution, procedures, interpersonal relationships among the 
employees and with their supervisors and also the sharing of information in a fair way in the hotel industry. Secondly, the factor of relationship was evaluated and determined with the organizational justice and the employee behavior based on innovation and also the contribution and function of the HRMPs between employee behavior and organizational justice within the organization that could lead towards the implication of both of the factors into the Hotel industry in an effective manner. In this particular study, the interpersonal relationships have been evaluated and examined among all the sub factors associated with the organizational justice and among all the sub factors regarding the employee work behavior in terms of innovation that may include the generation of innovative ideas, promotion of these ideas and the realization of these ideas based on innovation that reflect the innovative work behavior of employees working in the hotel industry. The findings carried out in this study provoked and emphasized mainly on the significance of the organizational justice in order to see innovative work behavior in employees working in these organizations and also in the HRMPs practices.

The findings carried out in this study led towards the result showing all of the variables were significantly correlated with each other that was found using the technique of correlation analysis for the data collected in this study. However, the findings carried out through the regression analysis concluded that there is a higher impact of organizational justice on the innovation of employees that means the innovative work behavior of employees increases when the organization has the proper implementation of justice within its work environment. Employees working in the hotel industry are the primary seekers of the fair treatment and equality while they are working that lead them towards showing a positive behavior and also their innovative working behavior increase due to organizational justice. The result obtained through the findings of this study can be supported through the study conducted by Hsu \& Wang (2015); Kim \& Lee (2013); Almansour \& Minai, (2012); Dutta, 2013 and de Spiegelaere et al. (2014) that state the significance of having organizational justice in organization in terms of fair treatments among the employees and promoting justice within the work environment and also the significant relationship between employee innovative work behavior and the organizational justice that shows employee work with a positive behavior and their creativity level increases when the organization is providing justice to employees and treats its employees equally. So, on the basis of the findings of these studies conducted by the previous researchers, it can be said that the perception of the fair treatment and justice is significant and highly impactful within the organizations and their working environment that has a direct impact on the employees working behavior in terms of creating new ideas, promoting those ideas and also the innovative implementation of those ideas for the betterment of the organization.

It has been found in this study that there is no significant impact of distributive justice on the innovative work behavior of employees working in the organizations as there is no impact of distributive justice on the innovation of employees has been found in this specific study. However, the previous studies conducted by Gozukara \& Yildirim (2016); Momeni et al., (2014); Hsu \& Wang, 2015 \& Janssen (2000) state that there is a significant relationship between distributive justice and employee innovative work behavior. These studies focused that the distributive justice is essential to be followed in the organizations in order to make the behavior of employees positive and to direct them towards bringing innovation in their work. The findings conducted in this study are quite different from these previous studies conducted in the similar study area by the previous researchers. But there are also some previous studies conducted on the impact of organizational justice and employee positive behavior that include the study conducted by Gozukara \& Yildirim (2016); Ismail et al. (2019) showed an insignificant relationship between distributive justice in organizations and the employee innovative working behavior. This study focused that there is no impact of distributive justice on the innovative working behavior of employees working in the organizations and the innovation factor does not get affected by it.

When it comes to Procedural justice, the findings of this study stated that it has a positive and significant relationship with the employee innovative working behaviors and with its sub factors. According to the study conducted by Kim \& Park (2017), procedural justice is essential for bringing out innovation in employees. So, it can be said if employees feel their sense of responsibility and performed them according to define a procedure which is based on justice then employee's behavior will be positive and they will put their efforts to introduce innovations and creativity. According to the findings carried out in this study, interpersonal justice also has a significant relationship with employee innovative working behavior and with 
the sub factors associated with it. The results obtained in this study can also be justified through the study conducted by Almansour \& Minai (2012) \& Upasna (2014) that stated there is a positive relationship between interpersonal justice and innovation that is specifically associated with the idea generation process of employees. There are more studies that justify the findings carried out in this study that include the studies conducted by Akram et al. (2016); Kim \& Lee (2013); Hsu \& Wang (2015) and many other studies that emphasized on the consistency in appreciating and rewarding employees on their good performance and fair evaluation of employees that would lead the employees to show a positive behavior towards work in terms of increasing creativity level and innovation in the employees.

\section{Conclusions}

Mediating effects of HRMPs in organizational justice on innovative work behavior of employees was studied in the present research paper. As suggested in literature Justice is a very important principle in society. Fundamentally, without justice, the well-being of employees is quite difficult. Each type of organizational justice has a different impact on employees working in an organization. Literature supports that distributive (Cohen-Charash \& Spector, 2001) and interactional justice are positively linked with the performance of employees (Iqbal et al., 2017) procedural justice is negatively linked as for as performance of employees and satisfaction is concerned (Tim, 1995). The current study showed that distributive justice has a negative impact on innovative work behavior of employees working in different hotels. Improper distribution of tasks, extra workload and pressure to complete the task on an urgent basis can be the cause of negative impact on innovative work behavior of employees. This dimension must be considered because for justice; tasks of employees must be equally distributed. Others dimensions of organizational justice have a positive impact. In mediation scenario (HRMP) are positively mediating between organizational justice and innovative work behavior of employees. Finally, there is a need to focus on each employee. Each should be treated in well-mannered and equally, because employees are assets for the hotel industry if they will be treated with justice then the hotel industry can grow. Well, in that case, the great responsibility lies in management which ensures that justice with its all dimensions in hotels is implemented. Tasks, Jobs and rewards distribution should be fair and without any discrimination. Procedures and process should be clearly defined. Employee behavior impacts a lot that's why interpersonal communication should be clear and fair. Information sharing must be accurate for taking the right decision on the right time because in hotels policies change according to the situation so, employees must be well trained to adopt change. Hotels are trying hard for becoming more competitive because this is the era of technology and innovation so for becoming more competitive employees should be competent, loyal, trustworthy, satisfied and motivated that can only be possible if they are treated in well-mannered and with justice.

\section{Limitations and Future Research Directions}

In spite of the fact that this study gives significant implications to innovative behavior, HRMPs and organizational justice literature with regards to the hotel industry still it is liable to few limitations. The data was collected only from hotels located in big cities of Pakistan; which needs further expansion to other cities and countries as well other than Pakistan to broaden the scope of the study. Furthermore, research is required to identify green HRMPs which can play an important role in supporting the relationship of organizational justice and innovative work behavior. Future research could be conducted by including control variables i.e. age gender these could be used as mediating variable to know their impact between organizational justice and innovative work behavior of hotel' employees. Last but not the least, for this current study only middle and top management of hotels, is targeted so there is also a need to include the lower management to see the overall impact.

\section{References}

1. Adams, J. (1965). Inequity in Social Exchange. Adv. Exp. Soc. Psychol. 62, 335-343.

2. Adams, J. (1963), "Towards an understanding of inequity". J. Abnormal Soc. Psychol. 67: 422436.

3. Ahmed, M. M., Shabib ul Hassan. Shabbir, G. (2018). Effect of Human Resource Component on Workers' Performance, European Journal of Business and Management, Vol.10, No.10. 
4. Al-Abrrow, H. A., Ardakami, M. S., Harooni, A., \& Poul, M. H. (2013).The relationship between organizational trust and organizational justice components and their role in job involvement in education. International Journal of Management Academy, 1(1), 25-41.

5. Alzyoud, S., Partington, N. S., Mitchell, C., \& Tom-Dieck, D. (2017). Employee Innovation in the Hospitality Industry: the Mediating Role of Psychological safety.

6. Akram, T., Haider, J., M., Feng, X. Y. (2016). The Effects of Organizational Justice on the Innovative Work Behavior of Employees: An Empirical Study from China, Journal of Creativity and Business Innovation, Vol. 2.

7. Almansour, M. Y., \& Minai, S. M.(2012). The Relationship between Organizational Justice Components and Innovative Behavior in Arab Society. Evidence from Government Department in Jordan, Middle-East Journal of Scientific Research 12 (1): 46-51.

8. Awang, R., \& Ahmad, W. M. R. W. (2015). The impact of organizational justice of organizational citizenship behavior in Malaysian higher education. Mediterranean Journal of Social Sciences, 6 (5), 674.

9. Aiken, L. S., West, S. G. (1991). Multiple regression: Testing and interpreting interactions. Thousand Oaks, CA: Sage.

10. Amyan, M. M. (2016). The Impact of Training on the Performance of Employees Case Study Search and Rescue Team: Jordanian Civil Defense, International Business and Management, Vol. 12, No. 3, pp. 49-61. DOI:10.3968/8498

11. Buyers, L. (2017). Major Issues Facing the Hospitality Industry in 2017, Hospitality News \& Events. [online] Available at: https://impos. [Accessed 08 Jan 2018].

12. Bücker, J., \& Horst, E. Van der. (2017). Innovative Work Behavior: To What Extent and How Can HRM Practices Contribute to Higher Levels of Innovation Within SMEs? Issues of Human Resource Management. DOI: 10.5772/intechopen. 68433.

13. Bagri, Babu, \& Kukureti. (2010). Human resource practices in hotels: A study from the tourist state of uttrakan, india, Journal of human resource in hospitality and tourism, 9(3): 286-299.

14. Colquitt, J. A., Conlon, D. E., Wesson, M. J., Porter, C. O., Ng, K. Y. (2001). Justice at the millennium: a meta-analytic review of 25 years of organizational justice research. J. Appl. Psychol. 86:425. 10.1037/0021-9010.86.3.425

15. Cohen-Charash, Y., and Spector, P. E. (2001). The role of justice in organizations: A metaanalysis. Organizational Behavior and Human Decision Processes, 86: 278-321.

16. Ceylan, A., \& Sulu, S. (2011). Organizational injustice and work alienation. E+ M Ekonomie a Management (2), 65.

17. Chen, C. J., \& Huang, J. W. (2009), Strategic human resource practices and innovation performance - The mediating role of knowledge management capacity. Journal of Business Research, 62, 104-114. http://dx.doi.org/10.1016/j.jbusres.2007.11.016.

18. Chan, S. H., \& Kuko, O. M. (2011).A study of human resource recruitment, selection and retention issues in the hospitality and tourism, 10(4): 421-441.

19. Cheung, M. F. Y. (2013). The mediating role of perceived organizational support in the effects of interpersonal and informational justice on organizational citizenship behaviors. Leadership \& Organization Development Journal, 34 (6), 551-572. DOI: 10.1108/lodj-11-2011-0114.

20. De Jong, J. \& Den Hartog, D. (2010). Measuring innovative work behavior, Creativity and Innovation Management, Vol. 19 No. 1, pp. 23-36.

21. DeConinck, J. B. (2010). The effect of organizational justice, perceived organizational support, and perceived supervisor support on marketing employees' level of trust. Journal of Business Research, 63 (12), 1349-1355. DOI: 10.1016/j. Jbusres. 2010.01.003.

22. Damanpour, F., \& Gopalakrishnan, S. (1998). - Theories of organizational structure and innovation adoption: The role of environmental changell, Journal of Engineering and Technology Management, Vol.15, No.1, pp. 1- 24.

23. Devonish, D., \& Greenidge, D. (2010). The Effect of Organizational Justice on Contextual Performance, Counterproductive Work Behaviors, and Task Performance: Investigating the moderating role of ability- based emotional intelligence. International Journal of Selection and Assessment, 18(1), 75-86. 
24. Dutta, S. (2013). An interactive model of employee intrapreneurial behavior. (Ph.D.), Central Michigan University, Mount Pleasant, Michigan.

25. Dalal, R. S. (2005). A meta-analysis of the relationship between organizational citizenship behavior and counterproductive work behavior. Journal of Applied Psychology, 90, 1241- 1255.

26. Erdoğdu, M. (2018). Effect of Organizational Justice Behaviors on Organizational Silence and Cynicism: A Research on Academics from Schools of Physical Education and Sports, Universal Journal of Educational Research 6 (4): 733-741.

27. G. Langford. (2016) .Travel and hospitality industry outlook. Available: https://goo.gl/yCYJoz.

28. Greenberg, J. (2006). Losing sleep over organizational injustice: Attenuating insomniac reactions to underpayment inequity with supervisory training in interactional justice. Journal of Applied Psychology, 91(1): 58-69.

29. Gozukara, I., Yildirim, O., \& Yildiz, B. (2016). Innovative behavior: Relations with developmental culture, Psychological empowerment, Distributive justice, and organizational learning capacity. International Business Research, 9(10), 186-200. https://doi:10.5539/Ibr.V9n10p186.

30. Gan, L. J., Yusuf, M. H. (2018). Does Organizational Justice Influence Organizational Citizenship Behavior among Engineers? A Conceptual Paper, Proceedings of the International Conference on Industrial Engineering and Operations Management Bandung, Indonesia.

31. Gamage, P. (2014). Organizational Justice and Organizational Commitment to Employees in Star Class Hotels in Sri Lanka: A Dimensional Perspective, Journal of Hospitality Application and Research. Vol. 9.

32. Hitt, M. A., Keats, B. W., and DeMarie, S. M. (1998), Navigating in the New Competitive Landscape: Building Strategic Flexibility and Competitive Advantage in the 21st Century, Academy of Management Executive 12(4): 22-42.

33. Hazzi, O. A. (2012). Organizational Justice: The Sound Investment in Organizations. European Journal of Economics, Finance, and Administrative Sciences, (52).

34. Hussaina, Konarb, A. (2015). Measuring Service Innovation Performance through Team Culture and Knowledge Sharing Behavior in Hotel Services: A PLS Approach. Procedia-Social and Behavioral Sciences 224 ( 2016 ) $35-43$.

35. Harter, J. K., Schmidt, F. L., \& Hayes, T. L. (2002), Business-Unit-Level relationship between employee satisfaction, employee engagement, and business outcomes: A meta-analysis\|, Journal of Applied Psychology, Vol. 87, No. 2, pp. 268-279.

36. Hsu, J., Wang, J. (2015). Exploring the Effects of Organizational Justice on Employees' Innovative Behavior in the Hospitality Industry from the Aspect of Organizational Support. Revista de cercetare si interventie sociala. 49, 113-126.

37. Huselid, M. A. (1995). The Impact of human Resource management practices on turnover, productivity and corporate financial performance, Academy of Management Journal, Vol.38, No.3, pp. 635672.

38. Hornsby, J. S., Kuratko, D. F., \& Zahra, S. A. (2002). Middle managers' perception of the internal environment for corporate entrepreneurship: Assessing a measurement scale. Journal of Business Venturing, 17(3), 253-273.

39. Hendry, C., and Pettigrew, A. (1990) Human resource management: an agenda for the 1990s, International Journal of Human Resource Management, Vol. 1' No. 1, pp. 17-43.

40. Hee, O. C., \& Jing, K. R. (2018). The Influence of Human Resource Management Practices on Employee Performance in the Manufacturing Sector in Malaysia. International Journal of Human Resource Studies, 8(2), 129. DOI: 10.5296/ijhr.

41. Hoque, M. M. S. A., Awang, B. Z., Siddiqui, A. B., Sabiu, S. M. (2018). Role of Employee Engagement on Compensation System and Employee Performance Relationship among Telecommunication Service Providers in Bangladesh, International Journal of Human Resource Studies, Vol. 8, No. 3.

42. Hilsop, D. (2003). The complex relations between communities of practice and the implementation of technological innovations, International Journal of Innovation Manag.

43. Heidari and Saeedi. (2012). Studying the role of organizational justice on job satisfaction (Case study: An Iranian company).Journal of Basic and Applied Scientific Research, 2 (7), pp. 6459-6465. 
44. Iqbal, M. Z., Rehan, M., Fatima, A., Nawab, S. (2017). The Impact of Organizational Justice on Employee Performance in the Public Sector Organization of Pakistan. Int J Econ Manag Sci 6: 431. DOI: 10.4172/2162-6359.1000431.

45. Joseph, K. E., and Dai, C. (2009). HRM Practices and Organizational Performance: An Empirical Analysis, International Journal of Business and Management, Vol.4, No.8, pp. 117-127.

46. Jones, D. A., \& Skarlicki, D. P. (2013). How perceptions of fairness can change: A dynamic model of organizational justice. Organizational Psychology Review, 3 (2), 138-160.

47. Janssen, O. (2000). Job demands, perceptions of effort-reward fairness and innovative work behavior. Journal of Occupational and Organizational Psychology, 73(3), 287-302. York, NY.

48. Korczynski, M. (2002). Human Resource Management in Service Work, Palgrave Macmillan, New

49. Khatri N., (1999). Emerging issues in Strategic HRM IN Singapore, International Journal of Manpower, Vol.20, No.8, pp. 516-529.

50. Kim, Y., \& Lee, B. G. (2013). An analysis of the mediating effect of organizational justice on the performance in the virtual organization. International journal of software engineering and its applications, 7(1), 201-210.

51. Kim, W., Park, J. (2017). Examining structural relationships between work engagement, organizational procedural justice, knowledge sharing, and innovative work behavior for sustainable organizations. Sustainability 9:205 10.3390/su9020205.

52. Kaul, A., \& Luo, J. (2016). An Economic Case for CSR: The Comparative Efficiency of For-Profit Firms in Meeting Consumer Demand for Social Goods.

53. Koch, M. J., \& McGrath, R. G. (1996). Improving Labor Productivity: Human Resource Management Policies Do Matter, Strategic Management Journal, Vol.17, 335-54.

54. Krischer, M. M., Penney, L. M., \& Hunter, E. M. (2010). Can counterproductive work behaviors be productive? CWB as emotion-focused coping. Journal of Occupational Health Psychology, 15(2), 154.

55. Greenberg, J., \& Colquitt, J. A. (2006). Handbook of Organizational Justice. Mahwah, NJ: Lawrence Erlbaum Associates.

56. Laforet, S. (2013). Organizational innovation outcomes in SMEs: Effects of age, size, and sector. Journal of World Business, 48 (4), 490-502.

57. Leelamanothum, A., Na-Nan, K., \& Ngudgratoke, S. (2018). The Influences of Justice and Trust on the Organizational Citizenship Behavior of Generation X and Generation Y. Asian Social Science, 14 (5), 60. DOI: $10.5539 / a s s . v 14 n 5 p 60$

58. Lambert, E. G., Liu, J., \& Jiang, S. (2018). An Exploratory Study of Organizational Justice and Work Attitudes among Chinese Prison Staff. The Prison Journal, 98 (3), 314-333. DOI: $10.1177 / 0032885518764919$

59. Lamprakis, A., Alamani, K., Malliar, A., Grivas, I. (2018). The Organisational Justice as a Human Resources Management Practice and its Impact on Employee Engagement: The case of the Prefecture of Attica (Greece), Scientific Annals of Economics and Business, 65 (1), 2018, 65-79.

60. Mirkamali, M. S., Fini, S. A. A., Zeinalipour, H. (2010). A Study of Relationship between Organizational Justice and Job Satisfaction among Teachers in Bandar Abbass Middle Schools. Social and Behavioral Sciences. 5. 1986-1990.

61. Moynihan, L. M., Gardner, T. M., Park, H. J., \& Wright, P. M. (2001). HR Practices and Customer Satisfaction: The Mediating Link of Commitment. (CAHRS Working Paper 01-14), Ithaca, NY: Cornell University, School of Industrial and Labor Relations, Center for Advanced Human Resource Studies.

62. Momeni, M., Ebrahimpour, H., Ajirloo, B. M. (2014). Surveying the impact of inferential organizational justice on innovative work behavior, Singaporean journal of business economics and management studies Vol. 2, No.9.

63. Mbiu, A. K., \& Nzulwa, J. (2018). Influence of Human Resource Planning on employee productivity in county governments in Kenya, The strategic journal of business and change management, Vol. 5, Iss. 4, pp. $193-214$. 
64. Masood, T. (2010). Impact of Human Resource Management (HRM) Practices on Organizational Performance: A Mediating Role of Employee Performance. Jinnah University, Karachi: Doctoral dissertation Mohammad Ali.

65. Minbaeva, D. B. (2005), HRM practices and MNC knowledge transfer, Personal Review, Vol. 34, No. 1, pp. 125- 144.

66. Niehoff, B. P., \& Moorman, R. H. (1993). Justice as a mediator of the relationship between methods of monitoring and organizational citizenship behavior, Academy of Management Journal, Vol. 36 No. 3, pp. 527-556.

67. Noerchoidah, Harjanti. (2019). Exploring the relationship between procedural justice and innovative work behavior in hospitality industry, JMK, vol. 21, no. 1, 21-31.

68. Nieve, J., \& Quintana, A. (2016). Human resource practices and innovation in the hotel industry; the mediating role of human capital, tourism and hospitality research.

69. Oren, L., Tziner, A., Nohishon, Y., and Sharoni, G. (2013). The relationship between OCBs, Organizational justice, work motivation, and self-efficacy. Academy of economic studies, 15(34), 505- 517.

70. Okechukwu, W. (2017). Influence of Training and Development, employee performance on job satisfaction among the staff of school of technology management and logistics, Universiti Utara Malaysia (STML, UUM), Journal of Technology Management and Business (ISSN: 2289-7224), Vol. 04, No 01.

71. Osburn, H. G. (2000). Coefficient alpha and related. Internal consistency reliability coefficients. Psychological Methods, 5, 343-355.

72. Pablo, Z., Jyh-Ming, T. (2017). Employees justice perceptions as a factor influencing successful outsourcing in the hospitality industry, International Journal of Contemporary Hospitality Management, Vol. 29.

73. Pan, X., Chen, M., Hao, Z., and Bi, W. (2018). The Effects of Organizational Justice on Positive Organizational Behavior: Evidence from a Large-Sample Survey and a Situational Experiment. Front. Psychol. 8:2315.

74. Riccucci, N., Fuenzalida, J. (2018). The Effects of Politicization on Performance: The Mediating Role of HRM Practices. Review of Public Personnel Administration, 1-26.

75. Rousseau, D. M., \& Greller, M. M. (1994). Guest editors' overview: Psychological contracts and human resource practices. Human Resource Management, 33(3), 383-384. doi:10.1002/hrm.3930330307

76. Sookoo, N. (2014). Perceptions of injustice and alienation dynamics within the workplace. Journal of the Department of Behavioral Sciences, 3(1), 81-99.

77. Pekurinen, V. M., Valimaki, M., Virtanen, M., Salo, P., Kivimaki, M., Vahtera, J. (2017). Organizational justice and collaboration among nurses as correlates of violent assaults by patients in psychiatric care. Psychiatr. Serv. 68, 490-496. 10.1176/appi. Ps. 201600171.

78. Saad, K. S., \& Elshaer, A. I. (2017): Organizational Politics and Validity of Layoff Decisions: Mediating Role of Distributive Justice of Performance Appraisal, Journal of Hospitality Marketing \& Management, DOI: 10.1080/19368623.2017.1320257.

79. Schuler, R. S., \& Jackson, S. (1987). Linking competitive strategies with human resource management practices, Academy of management executive, 9(3), 207-219.

80. Schuler, R.S (1992). Strategic Human resource Management: Linking People with the needs of the Business, Organizational Dynamics, Vol.20, pp. 19-32.

81. Sulaiman, I. S. (2018). The Impact of Organizational Justice on the Counterproductive Work Behavior (CWB): A Field Study Conducted in the Jordan Customs, International Journal of Business and Social Science Volume 9.

82. Sulu, S., Ceylan, A., \& Kaynak, R. (2010). Work alienation as a mediator of the relationship between organizational injustice and organizational commitment: Implications for healthcare professionals. International Journal of Business and Management, 5(8), 27.

83. Silva, M. R., Caetano, A., \& Zhou, Q. (2012). Injustice contexts and work satisfaction: the mediating role of justice perceptions. Int. Journal of Business Science and Applied Management, Volume 7, Issue 1.

84. Timetric. (2013). The Global luxury hotel market: Key trends and opportunities for 2017, Retrieved 11/2013, from http://www.prweb.com/releases/2013/11/prweb11358955.html. 
85. Tim, L. (1995). Fairness as an antecedent to participative budgeting: examining the effects of distributive justice, procedural justice and referent cognitions on satisfaction and performance, Journal of Management.

86. Tan, C. L. \& Nasurdin, A. M. (2010). Human resource management practices and organizational innovation: An empirical study in Malaysia, Journal of Applied Business Research, Vol.2, No.4, pp. 105-115.

87. Upasna, A. A. (2014). Linking justice, trust and innovative work behaviors to work engagement, Personnel Review, Vol. 43 Issue: 1, pp.41-73.

88. Umar, R. M., Saleem, S., \& Majoka, R. I. (2016). Impact of organizational justice on customer satisfaction in the hospitality industry of Pakistan: The moderating role of uncertainty avoidance. Journal of Foodservice Business Research, 20 (1), 50-64. DOI: 10.1080/15378020.2016.1195214.

89. Van de Ven, A. H. (1986). Central problems in the management of innovation. Management science, 32(5), 590-607.

90. Xerri, M. J. (2014). Examining the Relationship between Organisational Justice, Job Satisfaction and the Innovative Behavior of Nursing Employees. International Journal of Innovation Management. 18 (1), 1450004- 1450004-22.

91. Yigito, B., and Balaban, O. (2018). Relationship between Organizational Justice and Employee Satisfaction: Evaluation of Human Resources Functions, EconWorld2018@Lisbon.

92. Onn, Y. C., Yunus, N. B. J., Yusof, H., binti, Moorthy, K., \& Ai Na, S. (2018). The mediating effect of trust on the dimensionality of organizational justice and organizational citizenship behavior amongst teachers in Malaysia. Educational Psychology, 1-22. DOI: 10.1080/01443410.2018.1426836.

93. Zhang, M., \& Zhang, L. (2012). Teacher's innovative work behavior and innovation climate. Chinese Journal of Ergonomics, 18, 1-6. 